\title{
Major contribution of prokaryotes to carbon fluxes in the pelagic microbial food webs of the Mediterranean Sea
}

\author{
Luca Zoccarato, ${ }^{*}$ Anna Malusà, Serena Fonda Umani \\ Laboratory of Marine Ecology, Department of Life Science, University of Trieste, via L. Giorgieri 10, 34127 Trieste, Italy \\ *Corresponding author: luca.zoccarato.88@gmail.com
}

\begin{abstract}
In this study, we carried out dilution experiments at the surface and in the mesopelagic and bathypelagic layers at 15 sites in the Mediterranean Sea that covered a wide range of trophic conditions. The main aim was to test the hypothesis that prokaryotes, and particularly heterotrophic prokaryotes, are pivotal in sustaining both nanoplankton and microzooplankton energy requirements at all of the considered trophic states. These data highlight that bacterivory is the major pathway of organic carbon transfer in the oligotrophic and meso-eutrophic environments. The microzooplankton mostly feed on prokaryotes, directly or indirectly (through nanoplankton exploitation), rather than on microalgae. Under eutrophic conditions, herbivory is the main trophic pathway; however, the heterotrophic prokaryotes always represent an important source of carbon. The lowest food-web efficiency (1.e., ratio between productivity of the highest trophic level and productivity of the lower trophic levels) was determined for the eutrophic status due to possible grazer satiation, which translates into an excess of autotrophic biomass available for export or transfer to higher trophic levels. The food-web efficiency is higher under mesoeutrophic and oligotrophic conditions, where the main pathway is bacterivory. In the mesopelagic and bathypelagic layers, only nanoplankton predation on heterotrophic prokaryotes was investigated. The food-web efficiency in these layers was relatively high and nanoplankton appear to efficiently exploit the available biomass of heterotrophic prokaryotes
\end{abstract}

Key words: Pelagic food web; microzooplankton; microphytoplankton; prokaryotes; Mediterranean Sea; dilution protocol.

Received: February 2016. Accepted: April 2016.

\section{INTRODUCTION}

The food-web efficiency can be defined as the ratio between the productivity of the highest trophic level and the productivity of the lower trophic levels (Rand and Stewart, 1998; Berglund et al., 2007). This is influenced by the length and complexity of the food web, because of energy losses during each transfer from one level to the next (Dickman et al., 2008). In the early 1980's, the classic pelagic food web was substituted by a more comprehensive model that included the microbial loop, which introduced more trophic interactions (Azam et al., 1983).

The microbes of the microbial loop are fundamental to ecosystem functioning, and in the photic zone of oligotrophic systems (i.e., open oceans), the picophytoplankton (i.e., the cyanobacteria and picoeukaryote fractions) and small autotrophic nanoplankton fix more carbon than the microphytoplankton (i.e., diatoms) (Sommer et al., 2002). The main grazers of prokaryotes are heterotrophic nanoplankton $(2-10 \mu \mathrm{m})$, and directly or indirectly, microzooplankton $(10-200 \mu \mathrm{m})$, and this grazing activity has critical roles in carbon transfer along the trophic food web and in remineralisation processes (Sherr and Sherr, 1994). Grazing pressure can also structure planktonic communities and control their biomass, diversity (James and Hall,
1998; Lessard and Murrell, 1998), and primary productivity (Burkill et al., 1995; Cotano et al., 1998).

Both microzooplankton and nanoplankton can heavily exploit prokaryotic communities at the sea surface (Tsai et al., 2012; Di Poi et al., 2013), and nanoplankton have been indicated as the largest source of prokaryotic mortality in bathypelagic regions (Fonda Umani et al., 2010). A broad literature has defined the role of microzooplankton as the main and most efficient grazers of microphytoplantkon (for reviews, see Calbet and Landry, 2004; Latasa et al., 2005; Gutiérrez-Rodríguez et al., 2013). Calbet and Landry (2004) reported that microzooplankton can consume on average two-thirds of planktonic daily primary production. This microzooplankton grazing activity thus represents a pivotal factor in the control of the fate of the microbial biomass within the pelagic food webs, and microzooplankton have an essential role in the oligotrophic systems that are typically microbial dominated (Siokou-Frangou et al., 2010).

Although the aphotic zone contains about $70 \%$ of the seawater volume of the Earth, its food webs remain little explored (Nagata et al., 2010). Deep-water communities have generally been considered to be controlled in a bottom-up fashion, because the prokaryote-to-grazer abundance ratio decreases from the surface, with a drastic reduction of the grazing pressure. However, prokaryotes 
have heterogeneous distributions because many of them are attached to sinking particles, which creates micro hot spots, where prey-predator interactions take place (Azam, 1998; Herndl et al., 2008; Arístegui et al., 2009; Nagata et al., 2010). Furthermore, Aristegui et al. (2009) reported that the prokaryote-to-grazer ratio of the euphotic layer is only halved for the mesopelagic and bathypelagic zones, and they thus re-evaluated the significance of this grazing. Recently, Pachiadaki et al. (2014) and Rocke et al. (2015) measured the grazing impact on prokaryotic bathypelagic communities and showed that their removal by this grazing can represent $>30 \%$ of the initial standing stock.

Another source of prokaryote loss in deep environments is through their viral lysis, although the relevance of this is still unclear. Fonda Umani et al. (2010) reported that on average, viral-induced mortality of prokaryotes represented a quarter of the total grazing loss of prokaryotes, and although the virus-to-host ratio in the bathypelagic realm increased by 10 -fold relative to that at the surface, Parada et al. (2007) suggested that viral-induced mortality is not as relevant as might be expected.

Assessment of the predator grazing pressure on prokaryotes is a key point for an understanding of the food-web efficiency, both in oligotrophic pelagic systems and in the most eutrophic coastal systems (Sommer et al., 2002). Recently, De Laender et al. (2010) used a linear inverse model approach to estimate that in microbial dominated trophic food webs, bacteria are four times more important than phytoplankton in the protist diet, while in herbivorous dominated food webs, the diet of protists consists of similar amounts of bacteria and phytoplankton.

The main hypothesis of the present study was that prokaryotes, and particularly heterotrophic prokaryotes, are pivotal in sustaining the energy requirements of both nanoplankton and microzooplankton over a wide range of trophic conditions. To test this, we compared the results of 68 surface dilution experiments (Landry and Hassett, 1982) that were carried out in the Mediterranean Sea. We also analysed 14 dilution experiments that were carried out in the mesopelagic and bathypelagic layers of the Mediterranean Sea, to determine the deep food-web efficiency.

\section{METHOIDS}

\section{Study area}

The Mediterranean Sea is considered to be an oligotrophic basin due to the low concentrations of nutrients and chlorophyll a (Krom et al., 1991; Antoine et al., 1995). This oligotrophy increases moving eastwards across the Mediterranean, as indicated by the large decreasing gradients of nutrient concentrations (Krom et al., 1993), primary production, autotrophic biomass, export of primary production (Danovaro et al., 1999; Dolan et al., 1999; Turley et al., 2000), and chlorophyll concentration (Williams, 1998). Only the few areas of the basin that are close to river mouths or are in upwelling zones are characterised by eutrophic conditions, and these have plankton communities where there are greater proportions of larger autotrophic and heterotrophic organisms (Karydis and Kitsiou, 2012).

Eighty-two dilution experiments were carried out in the Mediterranean Sea at 15 sites. From east to west, these were located in the Aegean Sea (sites V7, V10, VIERA), the Ionian Sea (sites CF_16, MS_03A, V6), the Otranto Strait (site OL_107), the Adriatic Sea (sites C1, O_37B, O_36), the Tyrrhenian Sea (site V2), the Ligurian Sea (site V1), the Balearic Sea (site V3), the Alboran Sea (site V4), and the Atlantic Ocean (site VA) (Fig. 1). As detailed in Tab. 1, 68 of these dilution experiments were carried out at the subsurface (depth, $0.5 \mathrm{~m}$ ) and 14 in the mesopelagic and bathypelagic realms (depths between $670 \mathrm{~m}$ and $3860 \mathrm{~m}$ ).

The sub-surface experiments were set-up following two strategies: 34 were designed to determine the microzooplankton grazing rates (including the effects of nanoplankton grazing; Stoecker et al., 2014); and 34 were designed to determine the nanoplankton grazing rates on prokaryotes in the absence of larger predators. The nanoplankton dilution experiments were performed simultaneously with the microzooplankton experiments, with the same sampled water used, and with these samples incubated together. For the mesopelagic and bathypelagic layers, only nanoplankton dilution experiments were performed.

Some of these data have already been published as part of the studies by Fonda Umani et al. (2010) and Di Poi et al. (2013) related to the Transmed oceanographic cruise, and the studies by Fonda Umani and Beran (2003) and Fonda Umani et al. (2012). These data are combined here with the new data from the dilution experiments that were carried out on board the R.V. Urania during the Obama oceanographic cruise from 24 March to 6 April 2011 (sites CF_16 and MS_03A in the northern Ionian Sea, and sites C1, O_37B and O_36 in the southern Adriatic Sea). The details are reported in the Supporting Information (sub-surface experiments, Supplementary Tabs. 1 and 2; mesopelagic and bathypelagic experiments, Supplementary Tab. 3).

\section{Dilution techniques}

\section{Microzooplankton dilution experiments}

Forty-eight litres of seawater was prefiltered through 200- $\mu \mathrm{m}$ mesh with a funnel placed at the end of the hose of the Niskin bottle (prefiltered seawater). Part of this water was further filtered through $0.22-\mu \mathrm{m}$ mesh using a peristaltic pump, to obtain the 'particle-free' water. Four replicates of four sets of dilutions $(100 \%$ whole seawater, and $80 \%, 50 \%, 10 \%$ seawater) were prepared in 2 -L in- 
cubation bottles filled with the relevant proportions of the prefiltered and particle-free sea water. One replicate of each dilution was immediately fixed $\left(\mathrm{T}_{0}\right)$ with $2 \%$ formaldehyde solution (buffered, 0.2- $\mu \mathrm{m}$ filtered). Three replicates of each dilution were incubated at the in situ temperature for $24 \mathrm{~h}$ (on the deck of the research vessel, or on the shore) in 600-L tanks with sea-water circulation. The bottles were kept in movement by the flowing water,

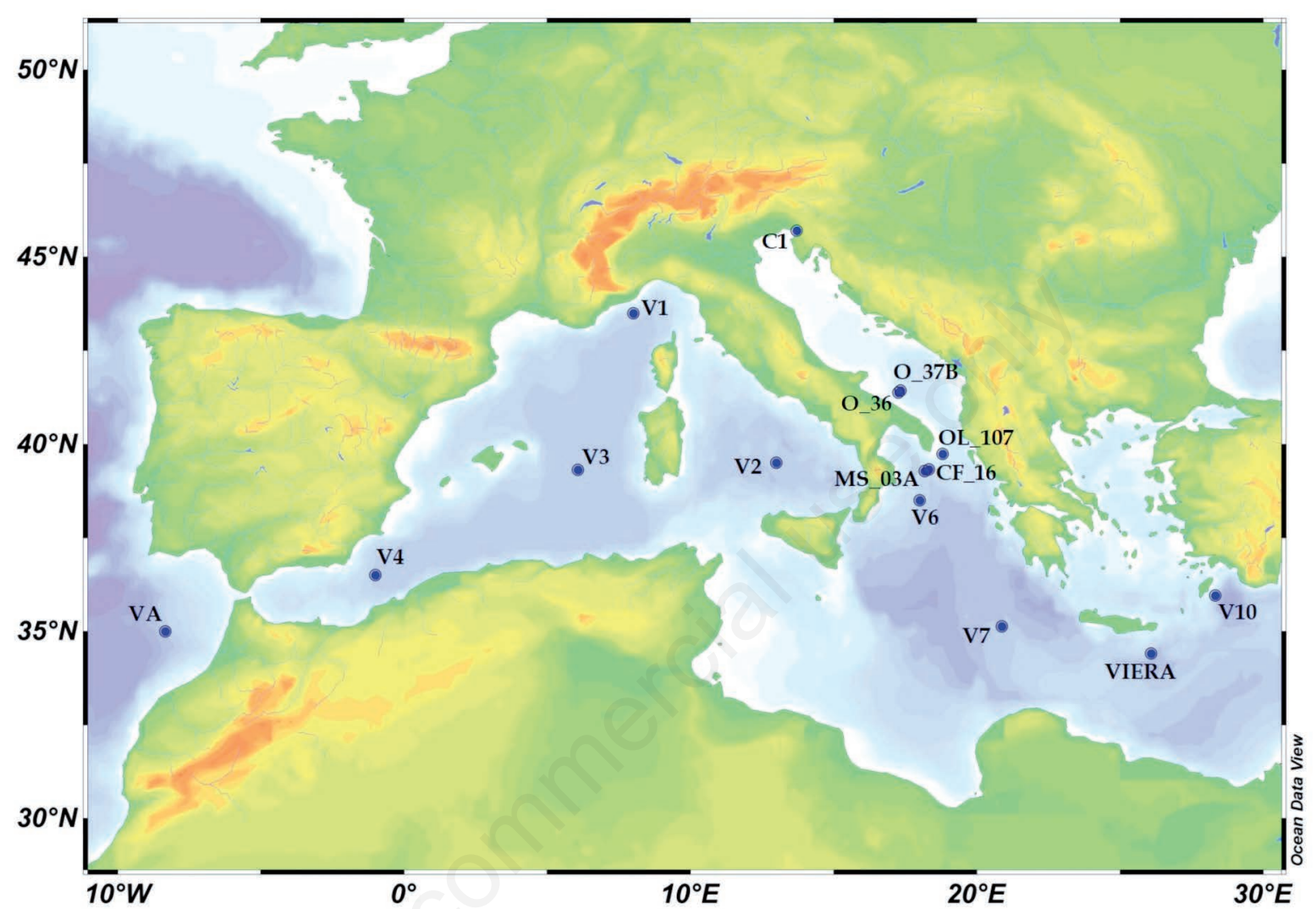

Fig. 1. Map of the Mediterranean Sea; dots indicate the sampling sites.

Tab. 1. Overview of the dilution experiments carried out on microzooplankton and nanoplankton at the sub-surface and in the mesopelagic and bathypelagic layers.

\begin{tabular}{|c|c|c|c|c|c|}
\hline \multirow{3}{*}{$\begin{array}{l}\text { Sampling } \\
\text { cruise }\end{array}$} & \multirow{3}{*}{$\begin{array}{l}\text { Station } \\
\text { code }\end{array}$} & \multicolumn{4}{|c|}{ Dilution experiment } \\
\hline & & \multicolumn{2}{|c|}{ Sea sub-surface } & \multicolumn{2}{|c|}{ Meso/bathypelagic realm } \\
\hline & & Microzooplankton & Nanoplankton & Nanoplankton & Depth (m) \\
\hline \multirow[t]{9}{*}{ Transmed } & V1 & 1 & 1 & 1 & 2480 \\
\hline & V2 & 1 & 1 & 1 & 3560 \\
\hline & V3 & 1 & 1 & 1 & 2840 \\
\hline & V4 & 1 & 1 & 1 & 2630 \\
\hline & V6 & 1 & 1 & 1 & 2990 \\
\hline & V7 & 1 & 1 & 1 & 3190 \\
\hline & V10 & 1 & 1 & 1 & 3860 \\
\hline & VA & 1 & 1 & 1 & 2770 \\
\hline & VIERA & 1 & 1 & 1 & 4750 \\
\hline \multirow[t]{6}{*}{ Obama } & O_36 & 1 & 1 & 1 & 1130 \\
\hline & O_- $37 \mathrm{~B}$ & 1 & 1 & 1 & 1100 \\
\hline & $\overline{C F}_{-} 16$ & 1 & 1 & 1 & 790 \\
\hline & MS_03A & 1 & 1 & 1 & 1030 \\
\hline & $\mathrm{OL}_{-} 107$ & - & - & 1 & 670 \\
\hline & $\overline{\mathrm{C}} 1$ & 20 & 20 & - & \\
\hline
\end{tabular}


and they were turned upside down manually every $3 \mathrm{~h}$ to $4 \mathrm{~h}$. At the end of this incubation, the samples were fixed $\left(\mathrm{T}_{24}\right)$, as the initial samples. The samples for the microzooplankton and microphytoplankton analyses were stored in plastic bottles in the cold cargo hold $\left(10-15^{\circ} \mathrm{C}\right)$ during the cruise, and then at $4^{\circ} \mathrm{C}$ in the laboratory. The samples for the nanoplankton analyses were stored in the dark at $4^{\circ} \mathrm{C}$ in black plastic bottles until laboratory analysis. The samples for the prokaryotes were immediately processed (see below) and then frozen at $-20^{\circ} \mathrm{C}$ until microscopy analysis.

In the oligotrophic eastern Mediterranean, the microphytoplankton were not considered, as the abundance was below the detection limit (Di Pol et al., 2013). In the other experiments, the in-situ phytoplankton growth rates were assessed without and with the addition of nutrients $(5 \mu \mathrm{M}$ $\mathrm{NaNO}_{3}, 1 \mu \mathrm{M} \mathrm{KH}_{2} \mathrm{PO}_{4}$ ) (Landry and Hassett, 1982).

\section{Nanoplankton dilution experiments}

Both at the surface and in the mesopelagic and bathypelagic layers, $12 \mathrm{~L}$ of seawater were collected, immediately pre-filtered through $200-\mu \mathrm{m}$ mesh and then filtered through $10-\mu \mathrm{m}$ mesh, to remove the larger predators. Sets of dilutions were prepared as for the microzooplankton, in $600-\mathrm{mL}$ bottles. For the sub-surface samples, the bottles were incubated together with the microzooplankton bottles, as above. The incubation bottles for the mesopelagic and bathypelagic dilution experiments were incubated in a cooler at the in-situ temperature and in the dark. The samples were then fixed and stored as described above.

The seawater for both the microzooplankton and nanoplankton dilution experiments was collected from the same conductivity, temperature and depth sensors cast.

\section{Microscopy analysis and cell-to-biomass conversion factors}

\section{Microplankton}

The samples for microphytoplankton and microzooplankton $(10-200 \mu \mathrm{m})$ were processed following the Utermöhl (1958) method. The original samples of seawater (2 L) were pre-sedimented for $72 \mathrm{~h}$ and then concentrated to $\sim 200 \mathrm{~mL}$ by gentle aspiration of the supernatant. After homogenisation, $50 \mathrm{~mL}$ to $100 \mathrm{~mL}$ of the samples was allowed to settle in a sedimentation cylinder, and the whole surface of the sedimentation chamber was examined. The organisms were counted and measured using an inverted optical microscope (Olympus IX51) equipped with an eyepiece scale. The standardised geometrical formulae used for the volume and carbon conversion factors were according to Hillebrand et al. (1999) and Menden-Deuer and Lessard (2000) for microphytoplankton, and Putt and Stoecker (1989) for microzooplankton. For the purpose of this study, we considered the major groups of the microzooplankton (i.e., aloricate cil- iates, tintinnids, micrometazoans, other protozoans) and the microphytoplankton as a whole.

\section{Nanoplankton and prokaryotes}

The assessment of the prokaryotes $(0.2-2 \mu \mathrm{m})$ and nanoplankton $(2-10 \mu \mathrm{m})$ was performed according to the Porter and Feig (1980) protocol using an epifluorescence microscope (Olympus BX 60 F5). Aliquots of each sample were stained with $1 \mu \mathrm{g} \mathrm{mL}^{-1}$ final concentration of 4', 6-diamidino-2-phenylindole (DAPI) solution. The prokaryotes were collected by filtering $2 \mathrm{~mL}$ to $15 \mathrm{~mL}$ with $0.22-\mu \mathrm{m}$ black polycarbonate filters (diameter, 25 $\mathrm{mm}$; Nucleopore), while the nanoplankton were collected by filtering $30 \mathrm{~mL}$ to $40 \mathrm{~mL}$ with $0.8-\mu \mathrm{m}$ black polycarbonate filters (diameter, $25 \mathrm{~mm}$; Nucleopore). The counting was carried out under the epifluorescence microscope at the final magnification of $1000 \times$, with a UV filter set [exciter filter (BP), 330-385nm; barrier filter (BA), 420 $\mathrm{nm}$ ] for DAPI, and green (BP 480-550 nm; BA $590 \mathrm{~nm}$ ) and blue (BP 420-480 nm; BA $515 \mathrm{~nm}$ ) light sets for the natural pigment fluorescence. More than 200 cells were counted for each prokaryote and nanoplankton sample. Three analytical replicates were analysed for the prokaryote counts. For the estimation of the biomass, the nanoplankton were divided into three classes according to their dimensions: $2-3 \mu \mathrm{m}, 3-5 \mu \mathrm{m}$ and $5-10 \mu \mathrm{m}$, as reported by Christaki et al. (2001). The abundances were converted to biomasses using $20 \mathrm{fg} \mathrm{C}$ cell $^{-1}$ for the heterotrophic bacteria at the surface (Ducklow and Carlson, 1992), $10 \mathrm{fg} \mathrm{C}$ cell $^{-1}$ for the heterotrophic bacteria in the mesopelagic and bathypelagic layers (Ducklow, 2000), and $200 \mathrm{fg} \mathrm{C}^{\mathrm{C}} \mathrm{cell}^{-1}$ for the phototrophic bacteria (Caron et al., 1995). The nanoplankton were approximated to spheres of diameter equal to the mean of each dimensional class, and the volume was multiplied by $183{\mathrm{fg} \mathrm{C} \mu \mathrm{m}^{-3}}^{-3}$ (Caron et al., 1995).

\section{Chlorophyll $a$}

For chlorophyll $a$ analysis, $1 \mathrm{~L}$ to $5 \mathrm{~L}$ of seawater was filtered through Whatman GF/F glass-fibre filters, and the filters were immediately frozen $\left(-20^{\circ} \mathrm{C}\right)$. For the pigment extraction, the filters were homogenised and extracted overnight in the dark at $4^{\circ} \mathrm{C}$ using $90 \%$ acetone. The chlorophyll $a$ concentrations were determined using a spectrofluorometer (Perkin Elmer LS 50B; excitation, 450 $\mathrm{nm}$; emission, $665 \mathrm{~nm}$ ) according to Lorenzen and Jeffrey (1980). The instrument was calibrated using pure Sigma chlorophyll $a$ standards for the linear response curve over the concentration range considered.

\section{Data elaboration}

Based on the dilution method of Landry and Hassett (1982), as modified by Landry et al. (1995), the following 
were calculated for the several classes of prey (i.e., microphytoplankton, nanoplankton, heterotrophic, autotrophic prokaryotes): growth factor $(\mu)$, mortality factor $(\mathrm{g})$, initial prey concentration $\left(\mathrm{C}_{0}\right)$, mean prey concentration during the experiment (equation 1), ingestion rate (equation 2), and potential production (equation 3 ).

$$
\begin{aligned}
& C_{m}=C_{0}\left(e^{(\mu-g) t}-1\right) /(\mu-g) \\
& I=g \times C_{m} \\
& P_{P}=\mu \times C_{m}
\end{aligned}
$$

where $t$ represents the incubation time (days), and $e$ is Nepero's number. Here, we considered only the results with significant linear regression for the prey considered $\left(\mathrm{r}^{2}>0.6\right)$.

The overall ingestion efficiencies of grazers under different trophic conditions are visualised through box plots that compare the ingestion rates and the corresponding prey potential production, as estimated in the microzooplankton dilution experiments. This potential production is considered to be a good proxy for the primary production (Calbet and Landry, 2004). The food-web efficiency was computed as the ratio of the highest trophic level production (in these truncated food webs, this corresponded to microzooplankton at the sub-surface and nanoplankton in the mesopelagic and bathypelagic layers) to the total potential production of all of the possible prey (Berglund et al., 2007). To determine whether the relationships between the ingestion rates of the grazers and the available biomasses of each kind of prey diverged from a linear response, three common models of functional responses were tested: Ivlev (equation 4), Holling Type II or the Disk Equation (equation 5) and Holling Type III (equation 6):

$$
\begin{aligned}
& I=\alpha\left(1-e^{-b C_{0}}\right) \\
& I=\alpha C_{0} /\left(\beta+C_{0}\right) \\
& I=\alpha C_{0}^{2} /\left(\beta^{2}+C_{0}^{2}\right)
\end{aligned}
$$$$
\text { (eq. 4), }
$$$$
\text { (eq. 5), }
$$

where $\mathrm{I}$ and $\mathrm{C}_{0}$ are the ingestion rate and the biomass estimated in each microzooplankton dilution experiment, respectively, $\alpha$ and $\beta$ are constants that represent the maximum rate of ingestion and the biomass, respectively, at which we have $\alpha / 2$. The values for $\alpha$ and $\beta$ that minimised the residual sum-of-squares in each equation were computed with the non-linear least squares (nls) function implemented in the Stats package of R. The fits of only the models where the parameters were highly significant $(\mathrm{P}<0.01)$ were considered and compared in the analysis of variance (ANOVA) and using the maximum likelihood for the same data, using the Akaike information criterion (AIC) and the Bayesian information criterion (BIC) to evaluate the fitting quality of the models.

\section{RESULTS}

\section{Sub-surface experiments}

Fig. 2 shows the biomasses of all of the primary producers and the chlorophyll $a$ values assessed at the subsurface for each sampling event. The increasing biomasses were arbitrarily divided into three major groups: i) total autotrophic carbon fraction (i.e., biomass) $<6.44 \mu \mathrm{g} \mathrm{C} \mathrm{L}^{-1}$ and mean chlorophyll $a 0.22 \mu \mathrm{g} \mathrm{L}^{-1}$, considered as representative of the oligotrophic condition; ii) total autotrophic carbon fraction $<61.93 \mu \mathrm{g} \mathrm{C} \mathrm{L}^{-1}$ and mean chlorophyll $a$ $0.60 \mu \mathrm{g} \mathrm{L}^{-1}$, considered as meso-eutrophic; iii) total autotrophic carbon fraction $>100 \mu \mathrm{g} \mathrm{C} \mathrm{L}^{-1}$ and mean chlorophyll a $2.60 \mu \mathrm{g} \mathrm{L}^{-1}$, considered as very eutrophic (or eutrophicated). These groups showed significant differences between each other for both chlorophyll $a$ (one-way Kruskal-Wallis tests, $\mathrm{P}=0.002$ ) and biomass of primary producers $(\mathrm{P}<0.001)$. Analysis of the total biomass composition (i.e., biomass of all of the considered classes of organisms) for microzooplankton dilution experiments revealed differences among the groups of trophic condition defined above (see also Supplementary Tab. 1). Under the oligotrophic and meso-eutrophic conditions, the nanoplankton and prokaryotes constituted on average almost $80 \%$ of the total biomass (with the prokaryotes alone as $>60 \%$ ), while the microphytoplankton represented only a small fraction, mainly because of the presence of flagellates. Under oligotrophic conditions, the total biomass mainly comprised nanoplankton (mean, 27.4\%) and heterotrophic prokaryotes (46.8\%), whereas under meso-eutrophic conditions the total biomass almost equally comprised microphytoplankton (28.8\%), heterotrophic prokaryotes $(33.7 \%)$ and autotrophic prokaryotes $(21.1 \%)$. Under eutrophicated conditions, microphytoplankton dominated over microbial assemblages; they represented on average $91.1 \%$ of the total biomass and were mainly composed of diatoms. The microzooplankton biomass was relatively high under meso-eutrophic conditions (10.3\%), but showed means of $4.8 \%$ and $2.5 \%$ under oligotrophic and eutrophicated conditions, respectively.

The community composition of microzooplankton changed among these samples (Fig. 3) with significantly greater variation among the groups of different trophic conditions than within each group (ANOVA: $F=9.03$, $\mathrm{P}<0.001)$. Aloricate ciliates and dinoflagellates were the most abundant taxa under oligotrophic conditions (mean relative abundance, $44.6 \%, 24.3 \%$, respectively) and under meso-eutrophic conditions $(36.2 \%, 23.3 \%$, respectively), although under meso-eutrophic conditions, micrometa- 
zoans were also abundant (32.8\%). Under eutrophicated conditions, aloricate ciliates and micrometazoans were dominant (45.8\%, 32.3\%, respectively). Tintinnid abundance was higher under oligotrophic and eutrophicated conditions $(10.2 \%, 12.6 \%$, respectively) than under mesoeutrophic conditions $(6.7 \%)$.
The analysis of the ingestion rates of microzooplankton in terms of all of their prey was highlighted as the daily amount of ingested carbon, and showed increases according to the trophic conditions (Supplementary Tab. 2). The percentage composition of the prey ingested by microzooplankton varied according to prey availability and trophic

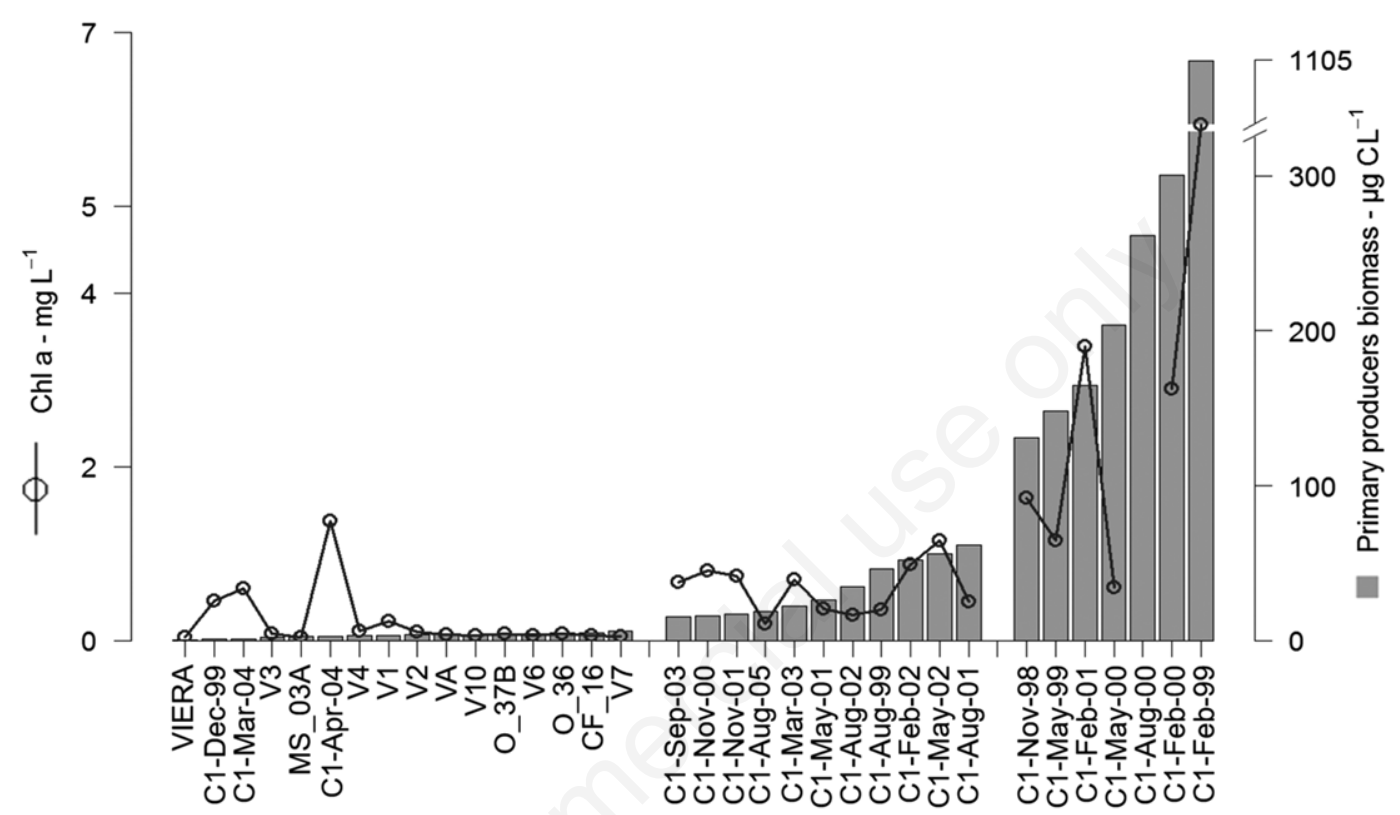

Fig. 2. Primary producer biomass and chlorophyll $a$ distribution.

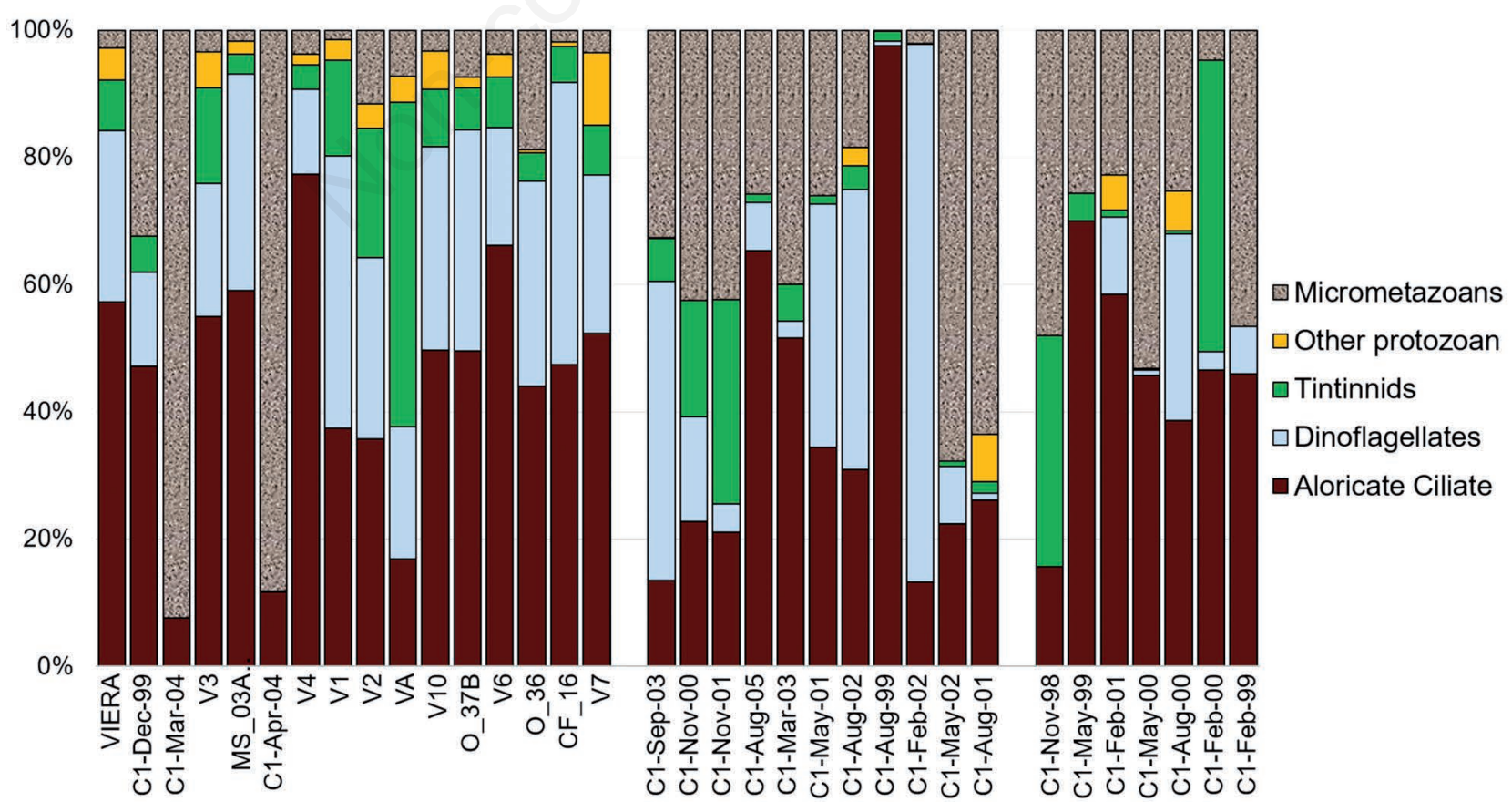

Fig. 3. Overview of the microzooplankton community compositions at the level of the major groups. 
state (Fig. 4). Under oligotrophic conditions, grazers mainly preyed on nanoplankton $(20.6 \%)$ and heterotrophic prokaryotes $(56.7 \%)$, and under meso-eutrophic situations, prokaryotes accounted for the main part of the microzooplankton diet $(60.6 \%, 10.0 \%$, for heterotrophic and autotrophic prokaryotes, respectively), compared to microphytoplankton (26.4\%). Under eutrophicated conditions, microphytoplankton represented the main part of the microzooplankton diet (74.2\%; with the relevant exception of February 1999; see Fonda Umani et al., 2012), with fewer heterotrophic prokaryotes consumed $(19.5 \%)$.

The comparison of the growth factor $(\mu)$ and the mortality factor (g) (Fig. 5a) can be considered as an estimation of the efficiency of the grazer in the control of the prey stocks. For each prey, the $g / \mu$ ratios showed no clear differences among the trophic conditions. On average, the distributions of $\mu$ and $g$ were close to the bisector, and thus to the energy balance, although in some instances g exceeded $\mu$. Fig. 5b illustrates the analysis of grazer ingestion efficiencies taking into account the biomass of the prey. The comparison of ingestion rates and the potential productions determined in the microzooplankton dilution experiments showed that these two rates were generally comparable, which is in agreement with the $\mu$ and $g$ analysis. However, under eutrophicated conditions, potential production of heterotrophic prokaryotes and especially of microphytoplankton greatly exceeded their ingestion rates, and this imbalance led to remarkable low ingestion efficiencies of grazers on these microphytoplankton and heterotrophic prokaryote prey.

Among the functional response models tested on the data from the microzooplankton dilution experiments, only the Holling Type III (H3) model provided significant fits, and only for heterotrophic prokaryotes, microphytoplankton and autotrophic prokaryotes (Fig. 6). Although significance was never reached in the ANOVA tests, there were differences for the statistical comparisons of the $\mathrm{H} 3$ model with the linear model for heterotrophic prokaryotes, microphytoplankton and autotrophic prokaryotes: the linear model better explained the data trends than the H3 model for autotrophic prokaryotes (AIC: 84.1, 96.9, respectively; BIC: 87.1, 99.8, respectively); no differences were observed for heterotrophic prokaryotes (AIC: 218.0, 217.9, respectively; BIC: 222.0, 221.9. respectively), and the $\mathrm{H} 3$ model better explained the data trends than the linear model for microphytoplankton (AIC: 224.8, 232.5, respectively; BIC: 228.7, 236.4, respectively). The $\alpha$ coefficient of the $\mathrm{H} 3$ model indicated an upper threshold $(\alpha)$ for the ingestion rates for microzooplankton on heterotrophic prokaryotes of $55.02 \mu \mathrm{g} \mathrm{C} \mathrm{L}^{-1} \mathrm{~d}^{-1}$, and on microphytoplankton of $197.2 \mu \mathrm{g} \mathrm{C} \mathrm{L}^{-1} \mathrm{~d}^{-1}$. The $\beta$ coefficient represents the point for the available biomass at which the curve undergoes inflection; after this point, the ratio between ingestion and biomass starts to decrease. $\beta$ was $17.63 \mu \mathrm{g} \mathrm{C} \mathrm{L}{ }^{-1}$ for heterotrophic prokaryotes, and 159.71

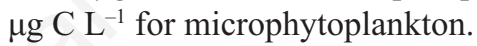

\section{Mesopelagic and bathypelagic experiments}

Fig. 7a illustrates the heterotrophic prokaryote biomasses estimated in the dilution experiments carried out for the mesopelagic and bathypelagic layers, where heterotrophic prokaryotes represented the only available prey for nanoplankton. The heterotrophic prokaryote biomass varied from $0.14 \mu \mathrm{g} \mathrm{C} \mathrm{L}^{-1}$ to $0.97 \mu \mathrm{g} \mathrm{C} \mathrm{L}^{-1}$, with the exception of two mesopelagic samples (i.e., CF_16,

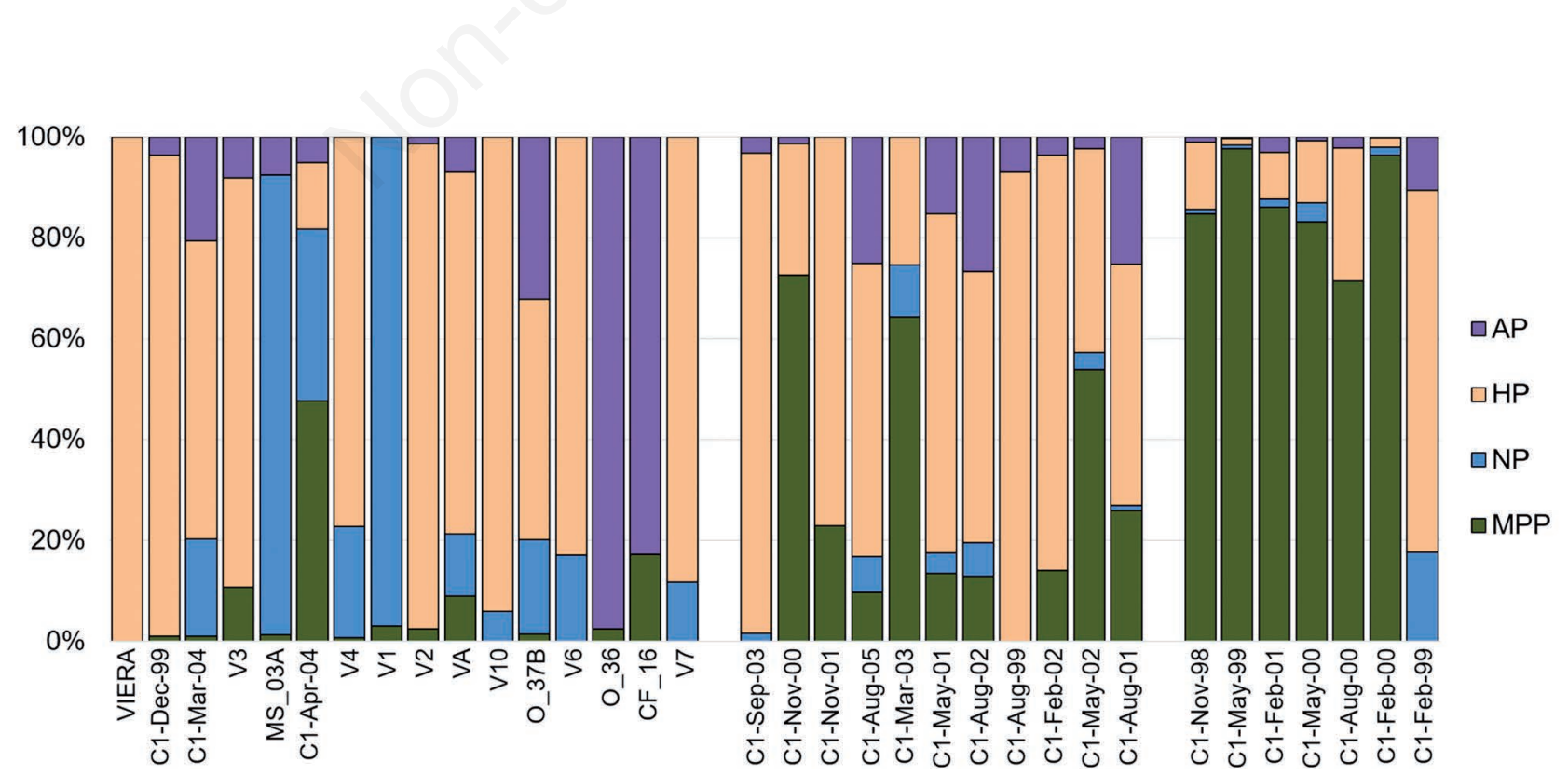

Fig. 4. Relative contribution of each prey to the total microzooplankton ingestion rates. 
OL 107) with relatively high heterotrophic prokaryote biomasses (7.24 $\mu \mathrm{g} \mathrm{C} \mathrm{L}^{-1}, 6.45 \mu \mathrm{g} \mathrm{C} \mathrm{L} \mathrm{C}^{-1}$, respectively). The mean biomass of nanoplankton for all of the sampling stations was $0.37 \mu \mathrm{g} \mathrm{C} \mathrm{L}{ }^{-1}$ (standard deviation, $\pm 0.31 \mu \mathrm{g}$
$\mathrm{C} \mathrm{L}^{-1}$ ). The $\mathrm{g} / \mu$ ratios for heterotrophic prokaryotes of the bathypelagic layers were on average close to the bisector (ratio 1:1; Fig. 7b). Remarkably, the $\mu$ values that exceeded the $g$ values were seen for the nanoplankton dilu- a)

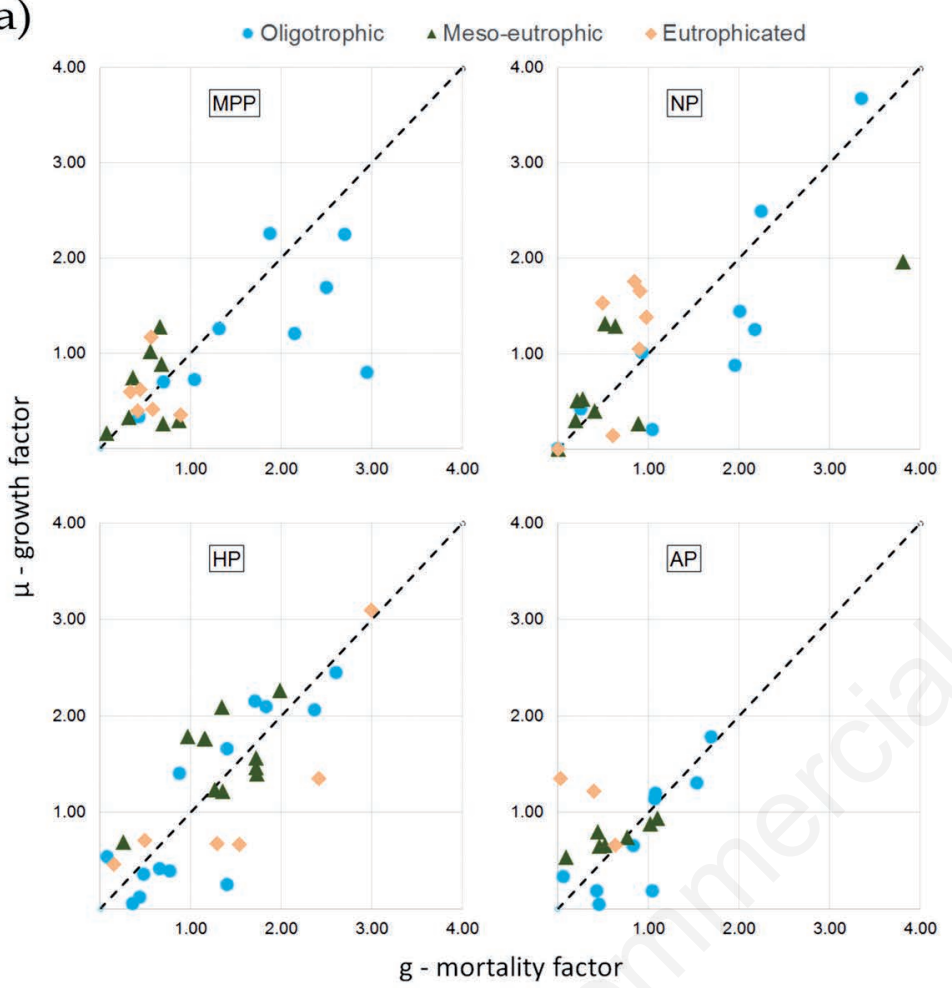

b)

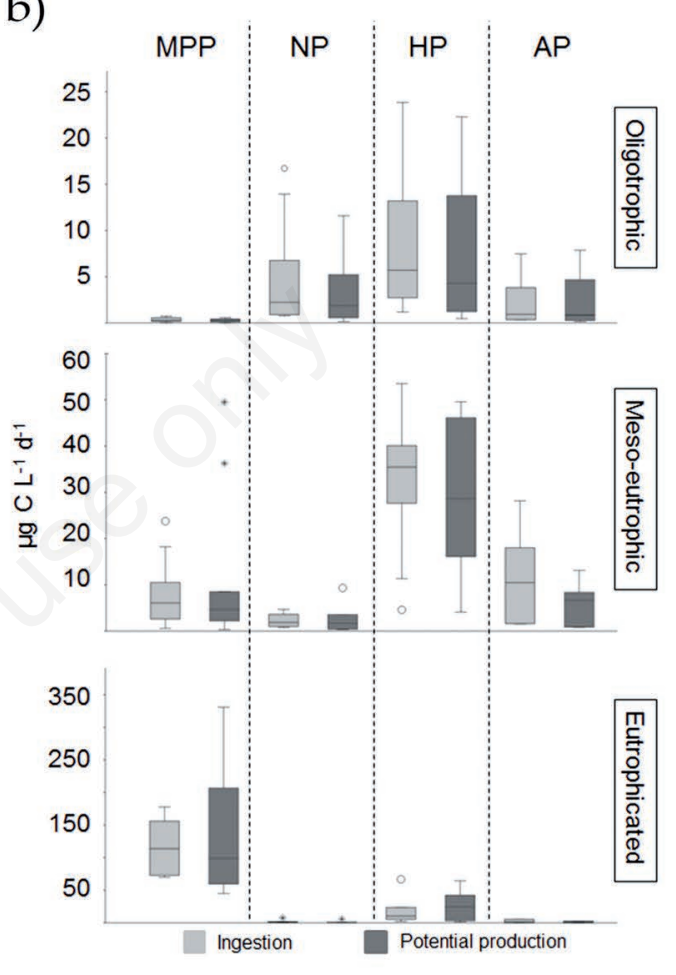

Fig. 5. a) Comparison of the growth factor $(\mu)$ and the mortality factor $(g)$. b) Box plot comparison of the potential productions and ingestion rates under all of the trophic conditions. MPP, microphytoplankton; NP, nanoplankton; HP, heterotrophic prokaryotes; AP, autotrophic prokaryotes.

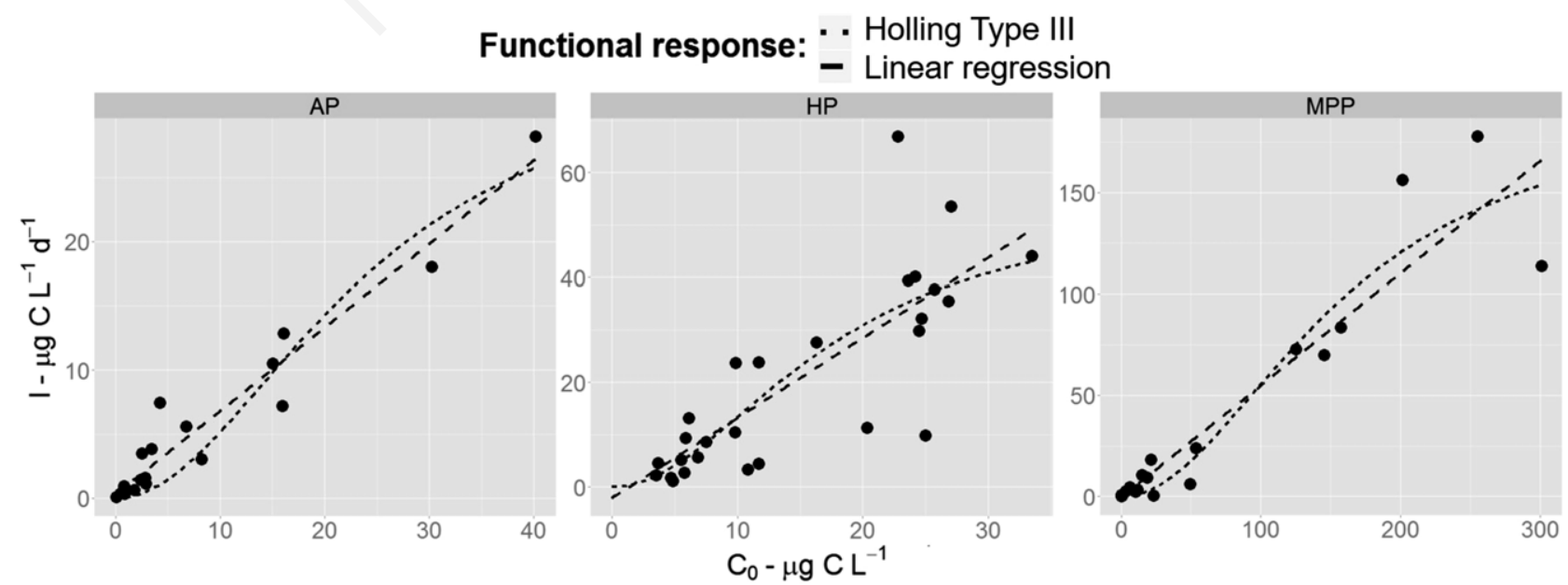

Fig. 6. Comparison between the ingestion rates and the available biomass. MPP, microphytoplankton; HP, heterotrophic prokaryotes; AP, autotrophic prokaryotes. The functional response models that provide a significant fits are reported. 
tion experiments carried out in the eastern Mediterranean Sea (i.e., V6, V7, VIERA, V10).

The comparison of the ingestion rates and potential productions highlighted these as similar, although there were some exceptions. For the deepest station (i.e., VIERA), the potential productions largely exceeded the ingestion rates. Moreover, stations CF_16 and OL_107 showed high potential productions and ingestion rates, where the ingestion rates exceeded the potential productions.

The functional response models were tested on the ba- thypelagic dataset, but none of them gave any significant fits, nor showed linear regression $\left(\mathrm{R}^{2}<0.2\right)$.

\section{C-flux models}

Fig. 8 shows the carbon flux schemes for the three trophic conditions described at the sub-surface and for the bathypelagic zone (no model was investigated here for the mesopelagic stations, as only two experiments were carried out). Under eutrophicated conditions, the prevalent ingestion by microzooplankton was for microphytoplank-

a)

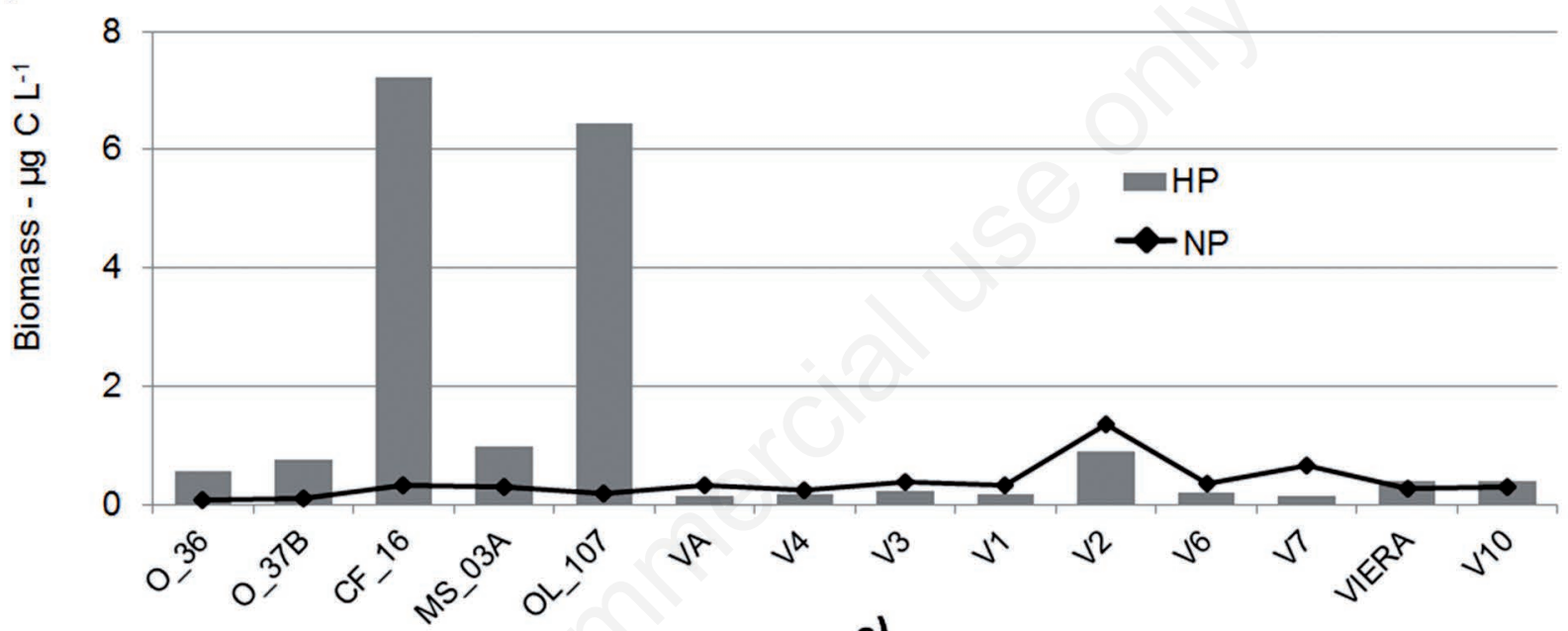

b)
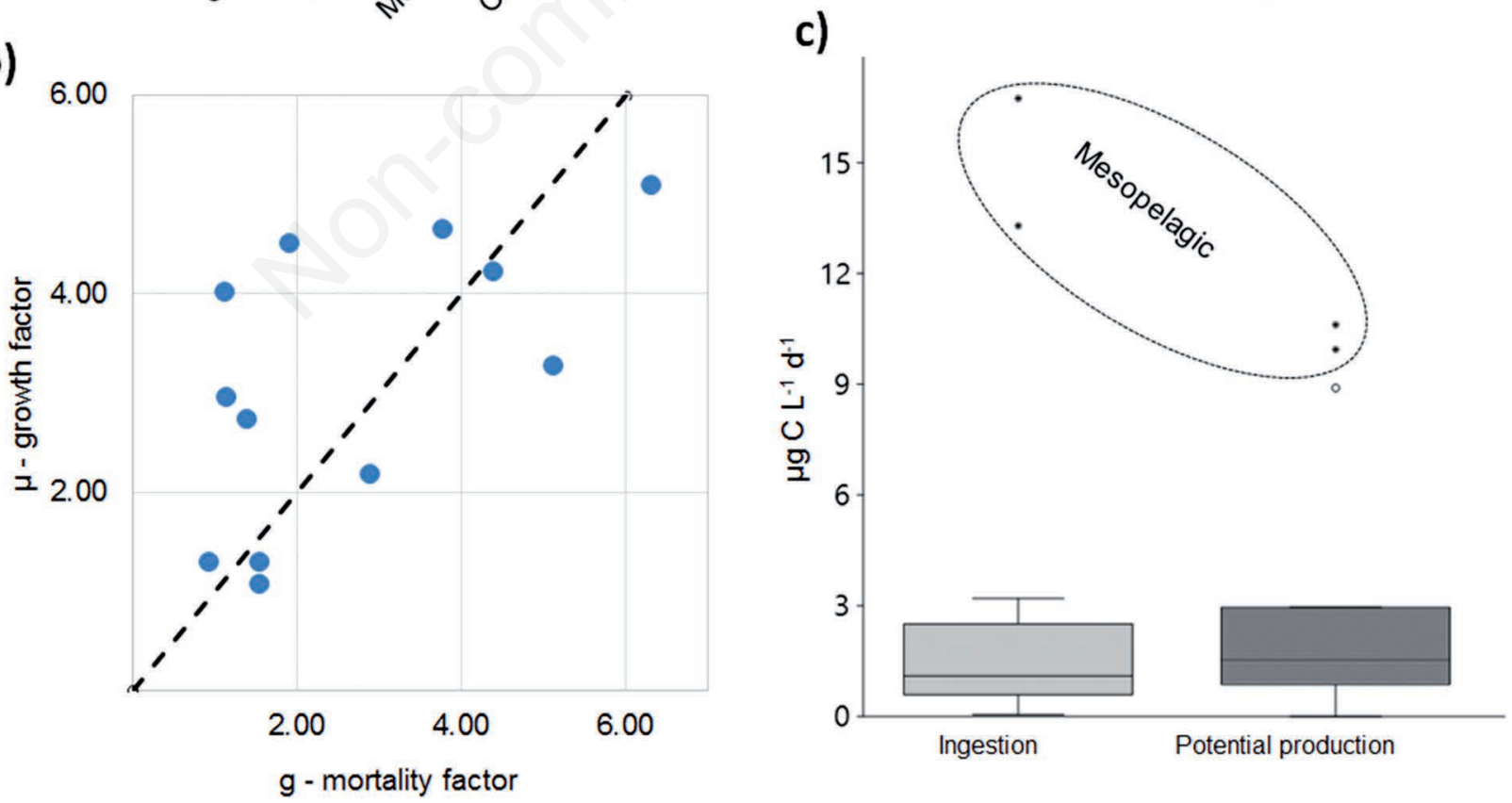

Fig. 7. a) Biomasses for the dilution experiments carried out in the mesopelagic and bathypelagic layers. HP, heterotrophic prokaryotes; $\mathrm{NP}$, nanoplankton. b) Comparison of the growth factor $(\mu)$ and the mortality factor $(\mathrm{g})$ for heterotrophic prokaryotes in the mesopelagic and bathypelagic layers. c) Box plot comparison of the ingestion rates and the potential productions for the mesopelagic (within the circle) and bathypelagic layers. 
ton, with mean ingestion rate of $112.4( \pm 45.6) \mu \mathrm{g} \mathrm{C} \mathrm{L} \mathrm{L}^{-1}$ $\mathrm{d}^{-1}$ and mean microphytoplankton biomass of 198.4 $( \pm 68.7) \mu \mathrm{g} \mathrm{C} \mathrm{L} \mathrm{L}^{-1}$ (one extremely high biomass was also recorded: $1104.3 \mu \mathrm{g} \mathrm{C} \mathrm{L}^{-1}$ ). Both microzooplankton and nanoplankton grazed on heterotrophic prokaryotes (mean ingestion rates, $11.3 \pm 8.2 \mu \mathrm{g} \mathrm{C} \mathrm{L}^{-1} \mathrm{~d}^{-1}, 14.8 \pm 6.3 \mu \mathrm{g} \mathrm{C} \mathrm{L}^{-1}$ $\mathrm{d}^{-1}$, respectively) with nanoplankton showing a greater impact, although without reaching statistical significance (one-way Kruskal-Wallis tests). Under meso-eutrophic conditions, grazers mainly preyed on heterotrophic prokaryotes (mean ingestion rate, $32.4 \pm 14.1 \mu \mathrm{g} \mathrm{C} \mathrm{L}^{-1} \mathrm{~d}^{-1}$ ), which was the most exploited stock (Kruskal-Wallis tests, $\mathrm{P}<0.001$ ), and the ingestion rates were significantly higher than those estimated in the presence of only nanoplankton (Kruskal-Wallis tests, $\mathrm{P}<0.5$ ). Under oligotrophic condi- tions, grazers mostly ingested heterotrophic prokaryotes $\left(9.0 \pm 8.2 \mu \mathrm{g} \mathrm{C} \mathrm{L}^{-1} \mathrm{~d}^{-1}\right)$, while remarkable ingestion by microzooplankton was seen for nanoplankton $(5.0 \pm 5.8 \mu \mathrm{g} \mathrm{C}$ $\mathrm{L}^{-1} \mathrm{~d}^{-1}$ ). In the experiments without microzooplankton, the nanoplankton grazing on heterotrophic prokaryotes (5.3 $\left.\pm 4.4 \mu \mathrm{g} \mathrm{C} \mathrm{L}^{-1} \mathrm{~d}^{-1}\right)$ was lower than the grazing determined in parallel microzooplankton dilution experiments, although the differences did not reach statistical significant (Kruskal-Wallis tests). The mean production of microzooplankton increased from $0.3( \pm 0.4) \mu \mathrm{g} \mathrm{C} \mathrm{L}^{-1} \mathrm{~d}^{-1}$ under oligotrophic conditions to $4.3( \pm 1.4) \mu \mathrm{g} \mathrm{C} \mathrm{L}^{-1} \mathrm{~d}^{-1}$ under meso-eutrophic conditions, and decreased to 1.0 $( \pm 0.6) \mu \mathrm{g} \mathrm{C} \mathrm{L}^{-1} \mathrm{~d}^{-1}$ under eutrophicated conditions.

The carbon flux for the deep layers was determined using only the bathypelagic data. Nanoplankton could
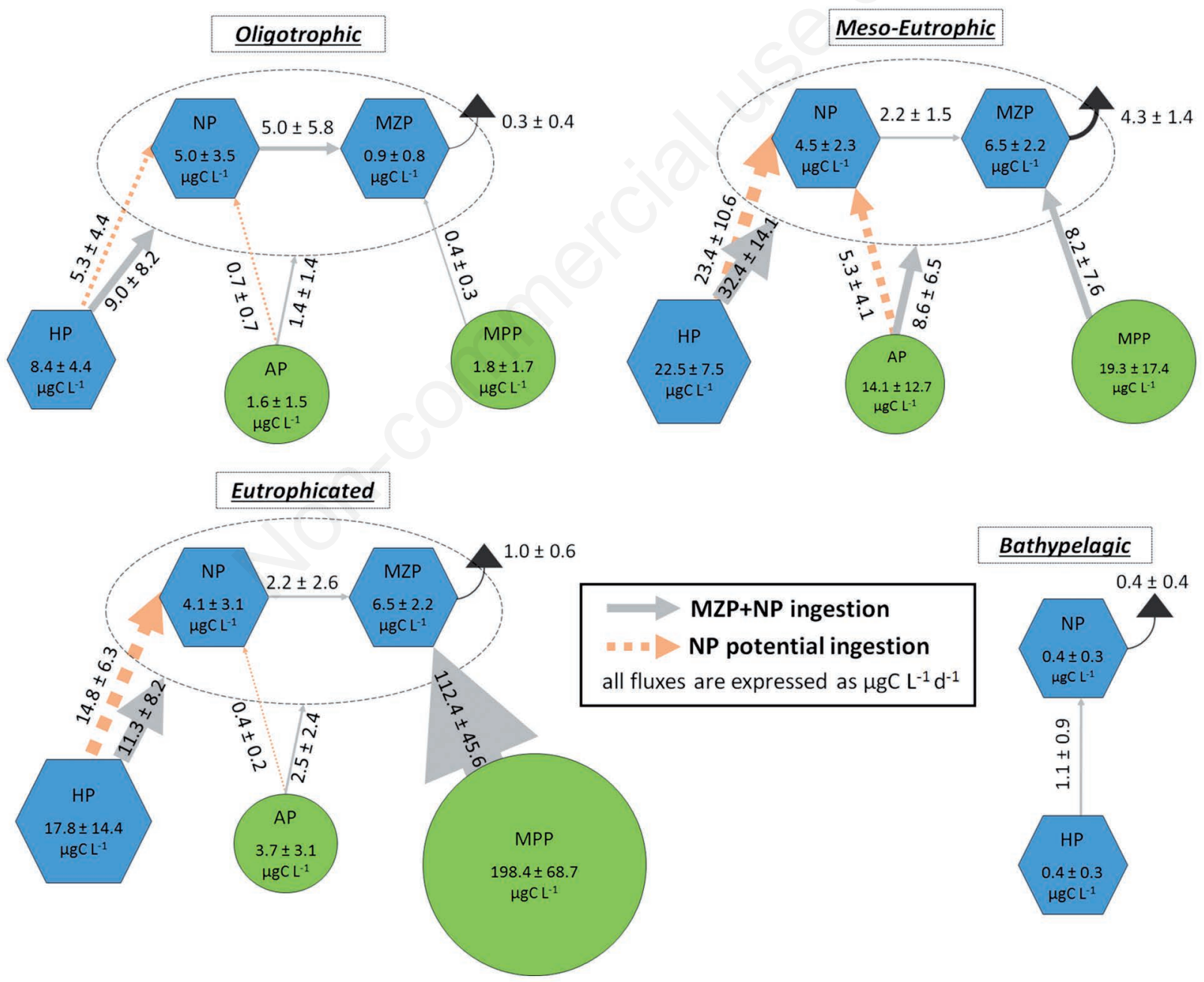

Fig. 8. Carbon flux models computed for the sub-surface and for the bathypelagic layers under the oligotrophic, meso-eutrophic and eutrophicated conditions. The models are composed of the mean ingestion rates $( \pm \mathrm{SD})$ of microzooplankton $(\mathrm{MZP})$, mean potential ingestion rates $( \pm \mathrm{SD})$ of nanoplankton (NP; dashed lines), and mean biomasses $( \pm \mathrm{SD})$ for all classes of organism. The secondary production $( \pm \mathrm{SD})$ is also reported for microzooplankton at the sub-surface and for nanoplankton in the bathypelagic layers. 
graze only on heterotrophic prokaryotes, with a mean ingestion rate of $1.1( \pm 0.9) \mu \mathrm{g} \mathrm{C} \mathrm{L}^{-1} \mathrm{~d}^{-1}$ on a mean biomass of $0.4( \pm 0.3) \mu \mathrm{g} \mathrm{C} \mathrm{L}^{-1}$. A production of $0.4( \pm 0.4) \mu \mathrm{g} \mathrm{C} \mathrm{L}^{-1}$ $\mathrm{d}^{-1}$ was estimated for nanoplankton.

With the food-web efficiency as the ratio between production at the highest level and production of all prey, as microphytoplankton, nanoplankton, heterotrophic prokaryotes and autotrophic prokaryotes, for the sub-surface this increased on average from oligotrophic to mesoeutrophic conditions $(0.03,0.10$, respectively), and decreased under eutrophicated conditions (0.01). In the mesopelagic and bathypelagic domains, the food-web efficiency that was computed considering nanoplankton as the top predators was 0.13 .

\section{DISCUSSION}

These data highlight that at the surface, prokaryotes (and particularly heterotrophic prokaryotes) were grazed by microzooplankton under all of the trophic conditions. The ingestion rates determined in the microzooplankton dilution experiments represented the concomitant predation impact of the microzooplankton and nanoplankton grazer communities (Stoecker et al., 2014), and to disentangle their effects, parallel microzooplankton and nanoplankton dilution experiments were performed. The mortality of each prey was thus estimated in the presence of both grazers and nanoplankton alone. This combined approach of the dilution technique and size fractioning was proposed by Calbet (2008), although the author addressed possible issues concerning whether or not microzooplantkonic cells pass through a $20-\mu \mathrm{m}$ mesh. In the present study, the size fractioning was carried out on 10$\mu \mathrm{m}$ mesh, and the samples were checked for the absence of larger cells during the microscopy analyses. The ingestion rates determined in the nanoplankton dilution experiments were not aimed at providing accurate estimations of nanoplankton grazing on prokaryotic communities. Our intention was instead to compare these values with the ingestion rates estimated in the microzooplankton dilution experiments, to clarify the role of microzooplankton as direct grazers on prokaryotes (see also Calbet et al., 2008). We are aware that these data here also include virus-mediated prokaryotic mortality (Parada, 2007; Fonda Umani et al., 2010; Di Pol et al., 2013), although such virus effects are expected to be the same in both the microzooplankton and nanoplankton dilution experiments, as the same seawater was used to set up these parallel dilution experiments.

Comparing the microzooplankton and nanoplankton ingestion rates on prokaryotes, three different situations can be defined for the grazer interactions with the prey (based on Fonda Umani and Beran, 2003): 1) strong reduction in nanoplankton by microzooplankton grazing, which translates into no detectable grazing on heterotrophic prokaryotes in the microzooplankton dilution experiments; 2) partial reduction in nanoplankton biomass by microzooplankton grazing, which leads to lower heterotrophic prokaryote mortality in the microzooplankton dilution experiments; and 3) microzooplankton directly feed on prokaryotes, and consequently the ingestion rates obtained in the microzooplankton dilution experiments are higher than for the nanoplankton dilution experiments. Situation 3 here was detected for heterotrophic prokaryotes in the majority of cases (i.e., 65\% of the experiments), and in all of the 11 dilution experiments under meso-eutrophic conditions. Situation 1 corresponded to $15 \%$ of all of the dilution experiments, and situation 2 to the remaining experiments. The direct impact of microzooplankton on prokaryotic assemblages was thus remarkable, especially for heterotrophic prokaryotes, which also represented the preferred prey under oligotrophic and meso-eutrophic conditions, as highlighted by the daily diet compositions. Also, under eutrophicated conditions when herbivory prevailed and microphytoplankton represented $>80 \%$ of the grazer diet, the ingestion rates on heterotrophic prokaryotes were relevant. This has deep implications in the dynamics of carbon fluxes in pelagic food webs, as microzooplankton represent the key players that channel organic carbon from the microbial loop through the upper trophic levels (Azam et al. 1983; Calbet and Saiz, 2005), and heterotrophic prokaryotes in the experiments analysed here had the highest biomass among the prey. Heterotrophic prokaryotes have generally been reported as dominant within the picoplankton communities in the western Mediterranean Sea and in the Aegean Sea, where the heterotrophic/ autotrophic biomass ratios varied between 0.5 and 3.0 (Christaki et al., 1996; PedrósAlió et al., 1999) and between 0.9 and 3.9 (Siokou- Frangou et al., 2002), respectively. The heterotrophic prokaryote biomass might thus be a fundamental source for the carbon budget in the Mediterranean pelagic ecosystem, and its variation can affect the carrying capacity of the pelagic food webs.

Aloricate ciliates, dinoflagellates and micrometazoans dominated the microzooplankton communities, although bacterivorous nanoplankton also contributed to the ingestion rates measured. In the literature, nanoflagellates are considered the most important grazers on prokaryotes (Caron and Finlay, 1994), and heterotrophic prokaryotes can represent up to $70 \%$ of the nanoflagellate diet (Tsai et al., 2012). Also, the mixotrophic fraction of flagellates strongly affects prokaryotic assemblages, accounting for $86 \%$ of the total flagellate grazing in Aarhus Bay, Denmark (Havskum and Riemann, 1996), while Urein et al. (2010) reported that a single species of Chrysophyta can consume up to $4.5 \%$ of the prokaryotic biomass in a coastal Mediterranean area. However, the sizes of these organisms ranged 
between $2 \mu \mathrm{m}$ and $20 \mu \mathrm{m}$, which in the present study corresponds to nanoplankton and the smallest fraction of microzooplankton. Bacterivory in microzooplankton has seldom been investigated. Rassoulzadegan et al. (1988) and Gonzalez et al. (1990) suggested the importance of ciliates as remarkable grazers of prokaryotes, although Ichinotsuka et al. (2006) reported that in coastal areas, the nanoflagellate impact is the highest.

Few studies have assessed the impact of microzooplankton grazing on planktonic communities in the Mediterranean Sea. The grazing pressure on prokaryotes has already been described in the Mediterranean Sea (Christaki et al., 1999; Fonda-Umani and Beran, 2003; Fonda-Umani et al., 2012; Di Poi et al., 2013), and the datasets of these studies were implemented in the present analysis, along with data from new dilution experiments. Heterotrophic prokaryotes were ingested two to five times more than microphytoplankton under oligotrophic and meso-eutrophic conditions, which is in agreement with the outcomes of De Laender et al. (2010). Conversely, when herbivory prevailed under eutrophicated conditions, heterotrophic prokaryotes were ingested at a quarter of the rate of microphytoplankton. More literature are available on phytoplankton as prey. The microzooplankton ingestion rates have been estimated to remove more than $50 \%$ of phytoplankton potential production (GutiérrezRodríguez et al., 2011), and cases in which the ingestion rates exceeded the potential productions are not uncommon (Latasa et al., 2005; Calbet et al., 2008). These literature results are in agreement with the global view provided by Calbet and Landry (2004) and with the ingestion rate/ potential production and $\mathrm{g} / \mu$ comparisons reported for microphytoplankton and autotrophic prokaryotes in the present study. The potential production of microphytoplankton exceeded the ingestion rate under eutrophicated conditions, while the ingestion rate on autotrophic prokaryotes exceeded the potential production under meso-eutrophic conditions. However, on average, there was a balance between the ingestion rate/ potential production values, and so there was efficient consumption of the newly produced biomass by microzooplankton. The efficiency of the grazer ingestion represents a proxy for the carbon balance of the system, although with some precautions that were suggested by Cáceres et al. (2013). If the grazing efficiency determined in microzooplankton dilution experiments is high (i.e., a ratio close to 1.0), the grazers (i.e., microzooplankton, nanoplankton) consume almost all of the potential production of the prey, and thus become the main gateway for the flux of the microbialloop-produced biomass towards the upper trophic levels. On the contrary, a low grazing efficiency leaves portions of unexploited prey biomass that can be used by predators larger than microzooplankton (e.g., mesozooplankton). This low grazing efficiency scenario represents a more complex food web, with a higher number of prey-predator interactions, which reduces the efficiency of the carbon transfer to the final consumers (San Martin et al., 2006; Berglund et al., 2007; Dickman et al., 2008).

At the sub-surface, the food-web efficiency reflected the ingestion efficiencies estimated for each prey, which was higher under the oligotrophic and meso-eutrophic conditions where there was full exploitation of the potential production of the prey by microzooplankton and nanoplankton grazers. Under eutrophicated conditions, the ingestion efficiency on heterotrophic prokaryotes was low, and was remarkably low for microphytoplankton. We are aware that the food webs considered are truncated, and that although the mesozooplankton community consumed on average only $10 \%$ of the daily global primary production (Calbet and Saiz, 2005), mesozooplankton can significantly affect both the microzooplankton and microphytoplankton communities under meso-eutrophic and eutroficated conditions (Ohman and Runge, 1994; Rivkin et al., 1996; Campbell et al., 2009; Fonda Umani et al., 2012). Larger predators can therefore exploit most of the excess of microphytoplankton biomass; however, low ingestion efficiencies have also been described for mesozooplankton, and downward export has been reported for several areas, such as the Gulf of Trieste (Fonda Umani et al., 2012) and the Bering Sea (Campbell et al., 2015).

In the bathypelagic layers, the biomasses of microzooplankton, nanoplankton and heterotrophic prokaryotes were lower than at the surface, and these fell within the ranges proposed by Nagata et al. (2010, and references therein). At two of the mesopelagic stations here (i.e., CF_16, OL_107), the heterotrophic prokaryote biomasses were comparable with those at the sub-surface under oligotrophic conditions, although the biomass of nanoplankton was one-tenth that at the sub-surface. The higher biomasses here might be correlated with the role of circulation and/or nutrient input from the upper euphotic layers, which enhanced heterotrophic prokaryote production (Hansell and Ducklow, 2003). However, in these two samples, the $g$ values exceeded the $\mu$ values, as well as the ingestion rates exceeding the potential productions, which indicated strong top-down control of nanoplankton, and the end of the ephemeral nature of the possible input events that triggered the increases in prokaryotic biomass. The low ratios between the heterotrophic prokaryote and nanoplankton biomasses found at CF_16 and OL_107 are in agreement with Pernice et al. (2015), who highlighted that on a global scale, the biomass ratio between eukaryotes and prokaryotes is constantly lower in the mesopelagic rather than the bathypelagic layers.

Although the mean biomass of heterotrophic prokaryotes in the mesopelagic and bathypelagic layers was $6 \%$ to $16 \%$ of the sub-surface biomass, the ingestion rates were from $13 \%$ to $58 \%$ of the sub-surface rates. This sug- 
gests strong feeding adaptation of nanoplankton under conditions of highly diluted prey, as reported by Cho et al. (2000) in the East China Sea, and more recently by Pachiadaki et al. (2014) for the eastern Mediterranean Sea and Rocke et al. (2015) for the North Atlantic Deep Water and the Antarctic Intermediate Water. All of these studies used fluorescently labelled prokaryote tracing techniques that have been shown to produce comparable, but lower, data with respect to those obtained in dilution experiments (Vaqué et al., 1994). New feeding strategies have been hypothesised for micro/ nano-eukaryotes in the deep sea, such as osmotrophy and parasitism (Pernice et al., 2015). However, the relatively high ingestion rates combined with the low heterotrophic prokaryote to nanoplankton abundance ratios emphasise the importance of grazing to satisfy the nanoplankton energy requirements.

The models of food webs constructed for these dilution experiments carried out at the sub-surface and in mesopelagic and bathypelagic layers provided simplified representations of natural networks, and the organisms were grouped in guilds based on their size and -trophy. Nevertheless, a comparison of the food-web efficiencies estimated at the sub-surface and in these deep regions would be meaningless considering the extreme simplicity of the deep water food web and the marked differences in the nutrient and light conditions, which are considered to have major impacts on food-web efficiency. However, the tight coupling between nanoplankton ingestion rates and heterotrophic prokaryote potential productions supports the importance of the heterotrophic prokaryote biomass to sustain the nanoplankton communities in the dark realms of the Mediterranean Sea, as underlined also by the coupling between the prey-predator biomasses. This aspect was highlighted by Pernice et al. (2015) and emphasises the relevance of the micro-hot-spots theory. Moreover, we indicate how nanoplankton might reach the limit of their control of the heterotrophic prokaryote communities in the eastern ultra-oligotrophic areas where growth overcomes the prey mortality factor.

The $\mathrm{H} 3$ model significantly described the correlation between ingestion rates and prey abundances for microphytoplankton and heterotrophic prokaryotes at the subsurface. In terms of goodness of fit and parsimony, the $\mathrm{H} 3$ model performed like the linear model for heterotrophic prokaryotes, while it explained the data trends even better for microphytoplankton. This prevalence of the sigmoidal model (i.e., the $\mathrm{H} 3$ model) over the liner model has some relevant ecological implications. In the oligotrophic, mesopelagic and bathypelagic regions, the microzooplankton and nanoplankton ingestion rates did not follow the slight biomass increases. This underlines the difficulties of microzooplankton and nanoplankton in the control of the prey communities at low density, which is likely to be due to reduced prey-predator encounter rates (Wikner and
Hagström, 1991; Pastor, 2008). In the mesopelagic and bathypelagic layers, grazers have evolved strategies to survive in such dilute environments (Jürgens and Massana, 2008), while at the surface, these adaptations might not be energetically convenient; for instance, under oligotrophic conditions, to sustain their energy requirements, the grazers relied on the more abundant nanoplankton and prokaryotes, rather than on microphytoplankton. The existence of a low abundance threshold for prey is partially supported also by the negative values of the linear model intercept, and confirms the prevalence of the bottom-up control of the resources over the top-down control of grazing in such environments (Dufour and Torréton, 1996; Hansell and Ducklow, 2003). The low ingestion efficiency under eutrophicated conditions can be interpreted as the result of individual inability of the grazer to cope with higher prey availability, as highlighted by the modelling approach of Gentleman and Neuheimer (2008). A possible explanation is a delay in the match of grazer growth with the prey increases, although the high satiation thresholds $(\alpha)$ suggested by the $\mathrm{H} 3$ model for microphytoplankton and heterotrophic prokaryotes were never reached in the experiments analysed here. The half saturation ( $\beta$ ) coefficient provided instead some interesting suggestions. $\beta$ values indicate the point after which the rate between ingestion and available biomass starts to decrease, which corresponded to prey availability of $159.71 \mu \mathrm{g} \mathrm{C} \mathrm{L}^{-1}$ and $17.63 \mu \mathrm{g} \mathrm{C} \mathrm{L}$ ${ }^{1}$ for microphytoplankton and heterotrophic prokaryotes, respectively. These two critical values were exceeded under eutrophicated conditions for microphytoplankton and under meso-eutrophic conditions for heterotrophic prokaryotes, and a possible ecological explanation might rely on a combination of satiation and the prey handling time of the grazers (Jeschke et al., 2012).

\section{CONCLUSIONS}

These suggested ecological implications nevertheless require to be tested on larger datasets, with the fitting analysis performed with more data in terms of ingestion rates acquired at very low and at high prey biomass availablity. Moreover, we have to keep in mind that these models tend to oversimplify networks of natural food webs, as there is strong evidence of intraguild predation (such as in microzooplankton; Franzé and Modigh, 2013) as well as the occurrence of mixotrophic life strategies (Mitra et al., 2016). These aspects might significantly affect the carbon fluxes described in the present study, and will need to be addressed in the future to achieve more reliable and accurate understanding of the pelagic food-web dynamics.

We are aware of the limitations of dilution experiments, because they cannot fully represent natural conditions. However, they can be used to compare different 
trophic situations when, as in the present case, they are set-up following the same protocol. The main results of our comparisons were:

- Bacterivory is the major pathway of organic carbon under oligotrophic and meso-eutrophic sub-surface conditions.

- Under eutrophicated conditions, herbivory is the main trophic pathway; however, prokaryotes represent a meaningful source of carbon.

- Pelagic food-web efficiency is higher when bacterivory is the dominant pathway, as herbivory is characterised by lower efficiency and can generate the export of biomass.

- In the mesopelagic and bathypelagic layers, nanoplankton ingestion rates of heterotrophic prokaryotes diminish, although not with the same order of magnitude as their biomasses, thus defining the relatively high efficiency of this truncated food web.

\section{ACKNOWLEDGMENTS}

We are grateful to all colleagues and SFU students who took part in the dilution experiments, to Giovanni Bacaro for his support with the statistical analysis, to Jack Koch for the review of the English grammar, to Mauro Celussi for his helpful feedback, and to the crews of the research vessels Urania and Universitatis.

We thank the editor and two anonymous reviewers for their constructive comments, which helped us to improve the manuscript.

\section{FUNDING}

This study was supported by the PERSEUS Project, managed by CONISMA, which provided a PhD Fellowship to LZ (grant number 287600).

\section{REFERENCES}

Antoine D, Morel A, André J-M, 1995. Algal pigment distribution and primary production in the eastern Mediterranean as derived from coastal zone color scanner observations. J. Geophys. Res. 100:16193-16209.

Arístegui J, Gasol JM, Duarte CM, Herndl GJ, 2009. Microbial oceanography of the dark ocean's pelagic realm. Limnol. Oceanogr. 54:1501-1529.

Azam F, 1998. Microbial control of oceanic carbon flux: the plot thickens. Science 280:694-696.

Azam F, Fenchel T, Field J, Gray J, Meyer-Reil L, Thingstad F, 1983. The ecological role of water-column microbes in the sea. Mar. Ecol.-Prog. Ser. 10:257-263.

Berglund J, Müren U, Båmstedt U, Andersson A, 2007. Efficiency of a phytoplankton-based and a bacterial-based food web in a pelagic marine system. Limnol. Oceanogr. 52:121-131.

Burkill PH, Edwards ES, Sleight MA, 1995. Microzooplankton and their role in controlling phytoplankton growth in the marginal ice zone of the Bellingshausen Sea. Deep-Sea Res. Pt. II 42:1277-1290.

Cáceres C, Taboada FG, Höfer J, Anadón R, 2013. Phytoplankton growth and microzooplankton grazing in the subtropical Northeast Atlantic. PLoS One 8: e69159.

Calbet A, 2008. The trophic roles of microzooplankton in marine systems. ICES J. Mar. Sci. 65:325-331.

Calbet A, Landry MR, 2004. Phytoplankton growth, microzooplankton grazing, and carbon cycling in marine systems. Limnol. Oceanogr. 49:51-57.

Calbet A, Saiz E, 2005. The ciliate-copepod link in marine ecosystems. Aquat. Microb. Ecol. 38:157-167.

Calbet A, Trepat I, Almeda R, Saló V, Saiz E, Movilla JI, Alcaraz M, Yebra L, Simó R, 2008. Impact of micro- and nanograzers on phytoplankton assessed by standard and size-fractionated dilution grazing experiments. Aquat. Microb. Ecol. 50:145-156.

Campbell RG, Ashjian CJ, Sherr EB, Sherr BF, Lomas MW, Ross C, Alatalo P, Gelfman C, Keuren D Van (2015). Mesozooplankton grazing during spring sea-ice conditions in the eastern Bering Sea. Deep-Sea Res. Pt. II (in press).

Caron D, Finlay B, 1994. Protozoan links in food webs, p. 125130. In: K. Hausmann and N. Hulsmann (eds.), Progress in protozoology. Gustav Fisher Verlag, Stuttgart.

Caron DA, Dam HG, Kremer P, Lessard EJ, Madin LP, Malone TC, Napp JM, Peele ER, Roman MR, Youngbluth MJ, 1995. The contribution of microorganisms to particulate carbon and nitrogen in surface waters of the Sargasso Sea near Bermuda. Deep-Sea Res. Pt. I 42:943-972.

Cho BC, Na SC, Choi DH, 2000. Active ingestion of fluorescently labeled bacteria by mesopelagic heterotrophic nanoflagellates in the East Sea, Korea. Mar. Ecol. Prog. Ser. 206:23-32.

Christaki U, Van Wambeke F, Christou ED, Conan P, Gaudy R, 1996. Food-web structure variability in the surface layer, at a fixed station influenced by the North Western Mediterranean Current. Hydrobiologia 321:145-153.

Christaki U, Giannakourou A, Van Wambeke F, Grégori G, 2001. Nanoflagellate predation on auto- and heterotrophic picoplankton in the oligotrophic Mediterranean Sea. J. Plankton Res. 23:1297-1310.

Cotano U, Uriarte I, Villate F, 1998. Herbivory of nanozooplankton in polyhaline and euhaline zones of a small temperate estuarine system (Estuary of Mundaka): seasonal variations. J. Exp. Mar. Bio. Ecol. 227:265-279.

Danovaro R, Dinet A, Duineveld G, Tselepides A, 1999. Benthic response to particulate fluxes in different trophic environments: a comparison between the Gulf of Lions, Catalan Sea (western Mediterranean) and the Cretan Sea (eastern Mediterranean). Prog. Oceanogr. 44:287-312.

De Laender F, Van Oevelen D, Soetaert K, Middelburg J, 2010. Carbon transfer in a herbivore- and microbial loop-dominated pelagic food webs in the southern Barents Sea during spring and summer. Mar. Ecol.-Prog. Ser. 398:93-107.

Di Poi E, Blason C, Corinaldesi C, Danovaro R, Malisana E, Fonda-Umani S, 2013. Structure and interactions within the pelagic microbial food web (from viruses to microplankton) across environmental gradients in the Mediterranean Sea. Global Biogeochem. Cycles 27:1034-1045. 
Dickman EM, Newell JM, González MJ, Vanni MJ, 2008. Light, nutrients, and food-chain length constrain planktonic energy transfer efficiency across multiple trophic levels. P. Natl. Acad. Sci. USA 105:18408-12.

Dolan JR, Vidussi F, Claustre H, 1999. Planktonic ciliates in the Mediterranean Sea: longitudinal trends. Deep. Res. Part I 46:2025-2039.

Ducklow H, 2000. Bacterial Production and biomass in the oceans, p. 85-120. In: D. Kirchman (ed.), Microbial ecology of the oceans. Wiley, New York.

Ducklow HW, Carlson CA, 1992. Oceanic bacterial production. Adv. Microb. Ecol. 12:113-181.

Dufour PH, Torréton J-P, 1996. Bottom-up and top-down control of bacterioplankton from eutrophic to oligotrophic sites in the tropical northeastern Atlantic Ocean. Deep-Sea Res. Pt. I 43:1305-1320.

Fonda Umani S, Beran A, 2003. Seasonal variations in the dynamics of microbial plankton communities: first estimates from experiments in the Gulf of Trieste, northern Adriatic Sea. Mar. Ecol.-Prog. Ser. 247:1-16.

Fonda Umani S, Malfatti F, Del Negro P, 2012. Carbon fluxes in the pelagic ecosystem of the Gulf of Trieste (northern Adriatic Sea). Estuar. Coast. Shelf S. 115:170-185.

Fonda Umani S, Malisana E, Focaracci F, Magagnini M, Corinaldesi C, Danovaro R, 2010. Disentangling the effect of viruses and nanoflagellates on prokaryotes in bathypelagic waters of the Mediterranean Sea. Mar. Ecol.-Prog. Ser. 418:73-85.

Franzé G, Modigh M, 2013. Experimental evidence for internal predation in microzooplankton communities. Mar. Biol. 160:3103-3112.

Gonzalez JM, Sherr EB, Sherr BF, 1990. Size-selective grazing on bacteria by natural assemblages of estuarine flagellates and ciliates. Appl. Environ. Microbiol. 56:583-589.

Gutiérrez-Rodríguez A, Latasa M, Scharek R, Massana R, Vila G, Gasol JM, 2011. Growth and grazing rate dynamics of major phytoplankton groups in an oligotrophic coastal site. Estuar. Coast. Shelf S. 95:77-87.

Hansell DA, Ducklow HW, 2003. Bacterioplankton distribution and production in the bathypelagic ocean: directly coupled to particulate organic carbon export? Limnol. Oceanogr. 48:150-156.

Havskum H, Riemann B, 1996. Ecological importance of bacterivorous, pigmented flagellates (mixotrophs) in the Bay of Aarhus, Denmark. Mar. Ecol.-Prog. Ser. 137:251-263.

Herndl GJ, Agogué H, Baltar F, Reinthaler T, Sintes E, Varela MM, 2008. Regulation of aquatic microbial processes: the 'microbial loop' of the sunlit surface waters and the dark ocean dissected. Aquat. Microb. Ecol. 53:59-68.

Ichinotsuka D, Ueno H, Nakano SI, 2006. Relative importance of nanoflagellates and ciliates as consumers of bacteria in a coastal sea area dominated by oligotrichous Strombidium and Strobilidium. Aquat. Microb. Ecol. 42:139-147.

James MR, Hall JA, 1998. Microzooplankton grazing in different water masses associated with the Subtropical Convergence round the South Island, New Zealand. Deep-Sea Res. Pt. I 45:1689-1707.

Jeschke JM, Kopp M, Tollrian R, 2012. Predator functional responses : discriminating between handling and digesting prey. Ecol. Monogr. 72:95-112.
Jürgens K, Massana R, 2008. Protist grazing on marine bacterioplankton, p. 383-441. In: D. Kirchman D (ed.), Microbial ecology of the oceans, $2^{\text {nd }}$ ed. J. Wiely \& Sons, Hoboken.

Karydis M, Kitsiou D, 2012. Eutrophication and environmental policy in the Mediterranean Sea: a review. Environ. Monit. Assess. 184:4931-4984.

Krom MD, Brenner S, Kress N, Neori A, Gordon LI, 1993. Nutrient distributions during an annual cycle across a warmcore eddy from the E. Mediterranean Sea. Deep-Sea Res. Pt. I 40:805-825.

Krom MD, Kress N, Brenner S, Gordon LI, 1991. Phosphorus limitation of primary productivity in the eastern Mediterranean Sea. Limnol. Ocean. 36:424-432.

Landry MR, Hassett RP, 1982. Estimating the grazing impact of marine micro-zooplankton. Mar. Biol. 67:283-288.

Landry MR, Kirshtein J, Constantinou J, 1995. A refined dilution technique for measuring the community grazing impact of microzooplankton, with experimental tests in the central equatorial Pacific. Mar. Ecol.-Prog. Ser. 120:53-64.

Latasa M, Morán XAG, Scharek R, Estrada M, 2005. Estimating the carbon flux through main phytoplankton groups in the northwestern Mediterranean. Limnol. Oceanogr. 50:14471458.

Lessard EJ, Murrell MC, 1998. Microzooplankton herbivory and phytoplankton growth in the northwestern Sargasso Sea. Aquat. Microb. Ecol. 16:173-188.

Lorenzen CJ, Jeffrey SW, 1980. Determination of chlorophyll in seawater. Unesco R. M. 35:1-20.

Menden-Deuer S, Lessard EJ, 2000. Carbon to volume relationships for dinoflagellates, diatoms, and other protist plankton. Limnol. Oceanogr. 45:569-579.

Mitra A, Flynn KJ, Tillmann U, Raven JA, Caron D, Stoecker DK, Not F, Hansen PJ, Hallegraeff G, Sanders R, Wilken S, McManus G, Johnson M, Pitta P, Våge S, Berge T, Calbet A, Thingstad F, Jeong HJ, Burkholder J, Glibert PM, Granéli E, Lundgren V, 2016. Defining planktonic protist functional groups on mechanisms for energy and nutrient acquisition; incorporation of diverse mixotrophic strategies. Protist 167:106-120.

Nagata T, Tamburini C, Arístegui J, Baltar F, Bochdansky AB, Fonda-Umani S, Fukuda H, Gogou A, Hansell DA, Hansman RL, Herndl GJ, Panagiotopoulos C, Reinthaler T, Sohrin R, Verdugo P, Yamada N, Yamashita Y, Yokokawa T, Bartlett DH, 2010. Emerging concepts on microbial processes in the bathypelagic ocean - Ecology, biogeochemistry, and genomics. Deep-Sea Res. Pt. II 57:1519-1536.

Ohman MD, Runge JA, 1994. Sustained fecundity when phytoplankton resources are in short supply: omnivory by Calanus finmarchicus in the Gulf of St. Lawrence. Limnol. Oceanogr. 39:21-36.

Pachiadaki MG, Taylor C, Oikonomou A, Yakimov MM, Stoeck $\mathrm{T}$, Edgcomb V, 2014. In situ grazing experiments apply new technology to gain insights into deep-sea microbial food webs. Deep-Sea Res. Pt. II 112:1-9.

Parada V, Sintes E, Van Aken HM, Weinbauer MG, Herndl GJ, 2007. Viral abundance, decay, and diversity in the meso- and bathypelagic waters of the North Atlantic. Appl. Environ. Microbiol. 73:4429-4438.

Pastor J, 2008. Mathematical ecology of populations and ecosystems. Wiley-Blackwell, Oxford: 344 pp.

Pedrós-Alió C, Calderón-Paz J-I, Guixa-Boixereu N, Estrada M, 
Gasol JM, 1999. Bacterioplankton and phytoplankton biomass and production during summer stratification in the northwestern Mediterranean Sea. Deep-Sea Res. Pt. I 46:985-1019.

Pernice MC, Forn I, Gomes A, Lara E, Alonso-Sáez L, Arrieta JM, del Carmen Garcia F, Hernando-Morales V, MacKenzie R, Mestre M, Sintes E, Teira E, Valencia J, Varela MM, Vaqué D, Duarte CM, Gasol JM, Massana R, 2015. Global abundance of planktonic heterotrophic protists in the deep ocean. ISME J. 9:782-792.

Porter KG, Feig YS, 1980. The use of DAPI for identifying and counting aquatic microflora. Limnol. Oceanogr. 25:943-948.

Putt M, Stoecker DK, 1989. An experimentally determined carbon: volume ratio for marine 'oligotrichous' ciliates from estuarine and coastal waters. Limnol. Oceanogr. 34:1097-1103.

Rand PS, Stewart DJ, 1998. Prey fish exploitation, salmonine production, and pelagic food web efficiency in Lake Ontario. Can. J. Fish. Aquat. Sci. 55:318-327.

Rivkin R, Legendre L, Deibel D, Tremblay J, Klein B, Crocker K, Roy S, Silverberg N, Lovejoy C, Mesple F, Romero N, Anderson M, Matthews P, Savenkoff C, Vezina A, Therriault J, Wesson J, Berube C, Ingram R, 1996. Vertical flux of biogenic carbon in the ocean: is there food-web control? Science 272:1163-1166.

Rocke E, Pachiadaki MG, Cobban A, Kujawinski EB, Edgcomb VP, 2015. Protist community grazing on prokaryotic prey in deep ocean water masses. PLoS One 10:e0124505.

San Martin E, Irigoien X, Harris RP, Lopez-Urrutia A, Zubkov MV, Heywood JL, 2006. Variation in the transfer of energy in marine plankton along a productivity gradient in the Atlantic Ocean. Limnol. Oceanogr. 51:2084-2091.

Sherr EB, Sherr BF, 1994. Bacterivory and herbivory: key roles of phagotrophic protists in pelagic food webs. Microb. Ecol. 28:223-235.

Siokou-Frangou I, Bianchi M, Christaki U, Christou E., Giannakourou A, Gotsis O, Ignatiades L, Pagou K, Pitta P, Psarra S, Souvermezoglou E, Van Wambeke F, Zervakis V, 2002. Carbon flow in the planktonic food web along a gradient of oligotrophy in the Aegean Sea (Mediterranean Sea). J. Mar. Syst. 33-34:335-353.

Siokou-Frangou I, Christaki U, Mazzocchi MG, Montresor M, Ribera d'Alcalá M, Vaqué D, Zingone A, 2010. Plankton in the open Mediterranean Sea: a review. Biogeosciences 7:1543-1586.

Sommer U, Stibor H, Katechakis A, Sommer F, Hansen T, 2002. Pelagic food-web configurations at different levels of nutrient richness and their implications for the ratio fish production:primary production. In: Vadstein $\mathrm{O}$, and Yngvar $\mathrm{O}$ (eds), Sustain. Increase Mar. Harvest. Fundam. Mech. New Concepts, Springer, pp. 11-20.

Stoecker DK, Weigel A, Goes JI, 2014. Microzooplankton grazing in the eastern Bering Sea in summer. Deep Sea Res. Part II 109:145-156.

Tsai AY, Gong GC, Sanders RW, Chiang KP, Chao CF, 2012. Heterotrophic bacterial and Synechococcus spp. growth and mortality along the inshore-offshore in the East China Sea in summer. J. Oceanogr. 68:151-162.

Turley CM, Bianchi M, Christaki U, Conan P, Harris JRW, Psarra S, Ruddy G, Stutt ED, Tselepides A, Van Wambeke F, 2000. Relationship between primary producers and bacteria in an oligotrophic sea - the Mediterranean and biogeochemical implications. Mar. Ecol. Prog. Ser. 193:11-18.

Unrein F, Gasol JM, Massana R, 2010. Dinobryon faculiferum (Chrysophyta) in coastal Mediterranean seawater: presence and grazing impact on bacteria. J. Plankton Res. 32:559-564.

Utermöhl H, 1958. [Zur Vervollkommnung der quantitativen Plankton-Methodik].[Article in German]. Mitt. Int. Ver. Theor. Angew. Limnol. 9:1-38.

Vaqué D, Gasol JM, Marrasé C, 1994. Grazing rates on bacteria - the significance of methodology and ecological factors. Mar. Ecol.-Prog. Ser. 109:263-274.

Wikner J, Hagström A, 1991. Annual study of bacterioplankton community dynamics. Limnol. Oceanogr. 36:1313-1324.

Williams PJL, 1998. The balance of plankton respiration and photosynthesis in the open oceans. Nature 394:55-57. 